\title{
Religious and spiritual coping in people living with HIV/Aids
}

\author{
Coping religioso e espiritual em pessoas vivendo com HIV/Aids \\ Estrategias de afrontamiento religioso y espiritual en personas que viven con VIH/SIDA
}

\section{Clarissa Mourão Pinho', Bruno Felipe Remigio Dâmaso", Eduardo Tavares Gomes', Maria de Fátima Cordeiro Trajano'"', Maria Sandra Andrade', Marília Perrelli Valença'}

' Universidade de Pernambuco, Faculty of Nursing Nossa Senhora das Graças, Associate Program in Postgraduate Program Nursing. Recife, Pernambuco, Brazil.

"Universidade de Pernambuco, University Hospital Oswaldo Cruz, Residency Program in Nursing. Recife, Pernambuco, Brazil.

I" Universidade Federal de Pernambuco, Postgraduate Program in Child and Adolescent Health. Recife, Pernambuco, Brazil.

How to cite this article:

Pinho CM, Dâmaso BFR, Gomes ET, Trajano MFC, Andrade MS, Valença MP. Religious and spiritual coping in people living with HIV/Aids. Rev Bras Enferm [Internet]. 2017;70(2):392-9. DOI: http://dx.doi.org/10.1590/0034-7167-2015-0170

Submission: 01-12-2016 Approval: 08-26-2016

\begin{abstract}
Objective: evaluate the religiosity and the religious/spiritual coping of people living with HIV/Aids. Method: descriptive, cross-sectional study with quantitative approach, conducted in a reference HIV/Aids outpatient clinic in a university hospital of Recife-PE, Brazil, from June to November 2015. At total of 52 people living with HIV/Aids (PLWHA) participated in the research, which employed own questionnaire, the Duke University Religion Index (DUREL), and the Religious/Spiritual Coping Scale (RCOPE). Results: the sample presented high indices of organizational religiosity $(4.23 \pm 1.66)$, non-organizational religiosity $(4.63 \pm 1.50)$, and intrinsic religiosity $(13.13 \pm 2.84)$. Positive RCOPE was used in high mean scores (3.66 \pm 0.88$)$, and negative RCOPE had low use ( $2.12 \pm 0.74)$. In total, use of RCOPE was high $(3.77 \pm 0.74)$, having predominated the positive RCOPE (NegRCOPE/PosRCOPE ratio $=0.65 \pm 0.46$ ). Conclusion: it is evident the importance of encouraging religious activity and RCOPE strategies, seen in the past as inappropriate interventions in clinical practice.

Descriptors: Spirituality; HIV; Long-term Survivors of HIV; Coping; Nursing.
\end{abstract}

\section{RESUMO}

Objetivo: avaliar a religiosidade e o coping religioso-espiritual de pessoas que vivem com HIV/aids. Método: trata-se de estudo transversal, descritivo, com abordagem quantitativa, realizado em um ambulatório de referência em HIV/aids de um hospital universitário do RecifePE, entre junho e novembro de 2015. Participaram da pesquisa 52 pessoas vivendo com HIV/aids (PVHA), utilizando-se questionário próprio, a escala de índice de religiosidade de Duke e a escala de coping religioso-espiritual (CRE). Resultados: a amostra apresentou elevados índices de religiosidade organizacional $(4,23 \pm 1,66)$, não organizacional $(4,63 \pm 1,50)$ e intrínseca $(13,13 \pm 2,84)$. O CRE positivo foi utilizado em escores médios altos $(3,66 \pm 0,88)$, e o CRE negativo teve baixo uso $(2,12 \pm 0,74)$. No total, o uso do CRE foi alto $(3,77 \pm 0,74)$, tendo predominado o CRE positivo (razão CREN/CREP $=0,65 \pm 0,46$ ). Conclusão: torna-se evidente a relevância de encorajar atividade religiosa e estratégias de CRE, vistas no passado como intervenções inadequadas dentro da prática clínica.

Descritores: Espiritualidade; HIV; Sobreviventes de Longo Prazo de HIV; Enfrentamento; Enfermagem.

\section{RESUMEN}

Objetivo: evaluar la religiosidad y las estrategias de afrontamiento religioso-espiritual en personas que viven con VIH/SIDA. Método: estudio transversal, descriptivo, con abordaje cuantitativo, llevado a cabo en un ambulatorio de referencia en $\mathrm{VIH} / \mathrm{SIDA}$ de un hospital universitario de la ciudad de Recife, Brasil, entre junio y noviembre de 2015. Del estudio, han participado 52 sujetos que viven con VIH/ SIDA, en lo cual se empleó cuestionario propio, la escala de religiosidad Duke, versión brasileña, y la escala de afrontamiento religiosoespiritual (CRE). Resultados: la muestra presentó altos índices de religiosidad organizacional $(4,23 \pm 1,66)$, no organizacional $(4,63 \pm 1,50)$ e intrínseco (13,13 $\pm 2,84)$. Se utilizó CRE positivo en puntajes medio altos $(3,66 \pm 0,88)$, y CRE negativo en bajos $(2,12 \pm 0,74)$. En total, la utilización de CRE fue alta $(3,77 \pm 0,74)$, siendo predominante CRE positivo (razón CREN/CREP $=0,65 \pm 0,46)$. Conclusión: se muestra relevante alentar las actividades religiosas y estrategias de CRE, en el pasado conocidas como inapropiadas en la práctica clínica.

Palabras clave: Espiritualidad; VIH; Sobrevivientes de Largo Plazo de VIH; Afrontamiento; Enfermería.

\section{CORRESPNDING AUTHOR Eduardo Tavares Gomes E-mail: edutgs@hotmail.com}




\section{INTRODUCTION}

History of the acquired immunodeficiency syndrome (AIDS) has changed considerably after the advent of the antiretroviral therapy (ART). In this context, it is relevant to note that Brazil, through the Unified Health System (SUS), has made available, free of charge, the medicines that are necessary for the disease, putting the country at the international forefront of Aids treatment ${ }^{(1)}$.

Aids is a chronic disease, but proper treatment reduces the probability of illness, mortality, virus transmission, in addition to improving quality of life for people living with the pathology ${ }^{(2)}$.

Diagnosis of HIV/Aids infection affects the individual, promoting psychological, physiological, and social alterations. Moreover, the numerous strict schedules of antiretroviral therapy - often with side effects, changes in lifestyle, and uncertainty and fear about the future - have significant impact. As a consequence, mental health problems - specially depression - may arise, often leading the individual to seek religious/ spiritual support, in addition to professional support, to cope with the disease ${ }^{(3-4)}$.

Religiosity is used as a way of strengthening by the individual in coping with the weaknesses that the disease can expose. Patients use faith as a source of strength, comfort, and hope for personal strengthening, to fight the disease, to try to understand the reason of such situation, and to reduce the fault imputed to those who get sick. It is also observed that patients who reported "no religion," but who believed in God, sought in Him a source of strength, comfort, and hope in coping with $\mathrm{HIV}^{(5)}$.

The disease is still subject to prejudice and stigma imposed by society, and people living with HIV/Aids suffer difficulties, as in entering the labor market or in personal relationships. Religiosity becomes important, favoring the coping with the new challenges that the disease can bring. In this sense, the health professional must provide biopsychosocial support, which comprises religiosity, seeking to understand the positive or negative expressions and relations in the experience of illness, trying to comfort the anxieties of users and help them in seeking autonomy ${ }^{(5)}$.

Therefore, it is relevant to conduct studies to deepen the analysis as to how people with HIV/Aids cope with the disease. Going beyond traditional observations about the impact of knowing of the disease, about the treatment, and about the social support for adaptation to the new conditions of life related to the disease, and taking as reference a new paradigm for health care focused on completeness, the observer discovers the reality of the patient's coping with the disease by religiosity and spirituality, aiming at better quality of life.

This study aimed to evaluate the religiosity and the religious/spiritual coping of people living with HIV/Aids.

\section{METHOD}

\section{Ethical aspects}

This research complied with the ethical precepts of Resolution No. 466/2012 of the National Health Council, and the research was approved by the Research Ethics Committee of the Hospital Universitário Oswaldo Cruz/Procape.

\section{Study design, location, and period}

This is a descriptive, cross-sectional study with quantitative approach, conducted in a reference HIV/Aids outpatient clinic in a university hospital of Recife-PE, Brazil, from June to November 2015. The hospital is a reference in infectious and parasitic diseases service in the state and receives patients from the entire Northeast region.

\section{Population and sample}

The study had participation of people living with HIV/Aids (PLWHA) who are provided regular care in the outpatient clinic, of both sexes, diagnosed with HIV for at least one year, aged from 18 years, who presented no cognitive alterations or neurological diseases that precluded participation in interview and who agreed to sign an informed consent. In the outpatient clinic, approximately 270 appointments are conducted per month.

To quantify the sample, sample size equation was applied for means, considering that the outcome variable is continuous quantitative. Among the scales used, we chose, as outcome to be considered in this estimation, the religious/spiritual coping scale, as it is the main variable and was used in a sample similar to the proposal ${ }^{(6)}$. We used error of $5 \%$, confidence level of $95 \%$, standard deviation of 0.366 , and error of 0.10 , estimating a sample of 52 patients, who were interviewed. There was no refusal to participate.

\section{Study protocol}

Patients were accosted in the interval between appointments and waiting room of the specialized clinic. After instruction about the research and written informed consent to participate, interviews occurred in a private location, and companions could watch if patients so desired.

To guide the interviews, we prepared a data collection instrument, consisting of a questionnaire for sociodemographic survey, such as sex, age, origin, income (in minimum wages, BRL 788 in the period), years of education, religious affiliation, and data on HIV/Aids, among others; in addition to the Duke University Religiosity Index and the Religious/Spiritual Coping Scale (RCOPE).

The Duke University Religiosity Index (DUREL) is a scale of five items, developed by Koenig et al. ${ }^{(7)}$, which measures three of the main dimensions of religious involvement related to outcomes in health: organizational religiosity (OR, item 1): frequency of religious gatherings (such as masses, cults, ceremonies, study groups, or prayer groups, etc.); non-organizational religiosity (NOR, item 2): frequency of private religious activities (such as prayers, meditation, reading of religious texts, and listening or watching religious programs on television or radio etc.); intrinsic religiosity (IR, items 3-5): pursuit of internalization and full experience of religiosity as main objective of the individual; immediate purposes are considered secondary and achieved in harmony with basic religious principles.

The religious-spiritual coping scale is an instrument adapted and validated for the Brazilian population - based on a North American scale - by Panzini and Bandeira, who also performed validation of construct, criteria, and content and determined the reliability of the RCOPE, finding appropriate psychometric properties ${ }^{(6)}$.

The instrument is composed of 87 items, which include questions relating to religion and spirituality to cope with stressing 
situations, instructing the participants to answer thinking specifically on the situation of the disease (HIV/Aids) ${ }^{(6)}$.

Answers are given in Likert-type scale with five points, ranging from 1 (not even a little) to 5 (very much). Correlation of the scale was carried out according to the criteria proposed by the authors and enabled determining the following scores:

- Positive RCOPE: indicates the level of positive religious/ spiritual coping exercised by the person evaluated, through the mean of 66 questions of the scale's positive dimension;

- Negative RCOPE: indicates the level of negative religious/ spiritual coping exercised by the participant, through the mean of 21 questions of the scale's negative dimension;

- Total RCOPE: indicates the total quantity of religious/ spiritual coping strategies used, through the mean between the positive RCOPE index and the mean of the reversed answers to the 21 items of the negative RCOPE.

As the two dimensions present reverse direction, we could not make the simple mean between the positive and negative strategies. Thus, estimation of total RCOPE is enabled by reversal of negative RCOPE, and the higher its value the higher the total use of RCOPE by the person evaluated ${ }^{(6)}$.

The parameters used for analysis of mean RCOPE values according to their use by respondents were: no or negligible: 1.00 to 1.50 ; low: 1.51 to 2.50 ; medium: 2.51 to 3.50 ; high: 3.51 to 4.50 ; very high: 4.51 to $5.00^{(6)}$.

The scale also allows evaluation of eight positive religious/ spiritual coping factors (transformation of self, of life; pursuit of spiritual help; offer of help to another one; positive attitude in relation to God; pursuit of spiritual growth; pursuit of the institutional other; pursuit of spiritual knowledge; and detachment by means of God/religion/spirituality) and four negative coping factors (negative re-evaluation of God; negative attitude in relation to God; negative re-evaluation of significance, and dissatisfaction with the institutional other) ${ }^{(6)}$.

\section{Analysis of results and statistics}

The data were stored and analyzed with resources of descriptive and inferential statistics, using Epi-info 7.0 and SPSS 20.0 software. Characterization of patients is performed by the frequency, and the scores are presented in mean, standard deviation, and range. Association between the scales and subscales used was assessed by Pearson correlation coefficient, being considered strong if $r \geq 0.8$, moderate if $0.3 \leq r<0.8$, and weak if $r<0.3$. Reliability in the use of scales was assessed by Cronbach's alpha, being considered with significant internal consistency (DUREL: $\alpha=0.83$; Total RCOPE: $\alpha=0.86$ ).

\section{RESULTS}

The sample was predominantly composed of male patients $(35 ; 67.3 \%)$, aged below 50 years $(33 ; 63.5 \%)$, single or with no companion $(75.0 \%)$, from the metropolitan region $(23 ; 44.2 \%)$ and from the capital $(21 ; 40.4 \%)$. Most were retired $(19 ; 36.5 \%)$ or employed $(17 ; 32.7 \%)$, with income of up to 1.5 minimum wage $(36 ; 69.2 \%)$, and with no child $(23 ; 44.2 \%)$.
The main religious affiliation was to the Catholic Church $(22 ; 42.3 \%)$ and Evangelical Churches (considering all denominations) $(19 ; 36.5 \%)$, and only one was an atheist $(1.9 \%)$. Considering this distribution and the sample size, in the statistical analysis the patients were considered as a single group, without division by category of affiliation.

Table 1 - Sociodemographic characterization of the patients of a reference HIV/Aids outpatient clinic, Recife, Pernambuco, Brazil, 2015

\begin{tabular}{|c|c|c|}
\hline Variables & $\mathbf{n}$ & $\%$ \\
\hline \multicolumn{3}{|l|}{ Sex } \\
\hline Male & 35 & 67.3 \\
\hline Female & 17 & 32.7 \\
\hline \multicolumn{3}{|l|}{ Age group } \\
\hline Up to 50 years & 33 & 63.5 \\
\hline 50 years and over & 19 & 36.5 \\
\hline \multicolumn{3}{|l|}{ Marital status } \\
\hline Married/with companion & 13 & 25.0 \\
\hline Unmarried/without companion & 39 & 75.0 \\
\hline \multicolumn{3}{|l|}{ Origin } \\
\hline Capital & 21 & 40.4 \\
\hline Metropolitan region & 23 & 44.2 \\
\hline Countryside & 8 & 15.4 \\
\hline \multicolumn{3}{|l|}{ Labor activity } \\
\hline Retiree & 19 & 36.5 \\
\hline Employee & 17 & 32.7 \\
\hline Self-employed professional & 6 & 11.6 \\
\hline Unemployed & 10 & 19.2 \\
\hline \multicolumn{3}{|l|}{ Income } \\
\hline Up to 1.5 minimum wage & 36 & 69.2 \\
\hline More than 1.5 minimum wage & 16 & 30.8 \\
\hline \multicolumn{3}{|l|}{ Number of children } \\
\hline No child & 23 & 44.2 \\
\hline 1 or 2 & 19 & 36.6 \\
\hline 3 or more & 10 & 19.2 \\
\hline \multicolumn{3}{|l|}{ Religion } \\
\hline Catholic & 22 & 42.3 \\
\hline Evangelical & 19 & 36.5 \\
\hline Spiritualist & 5 & 9.6 \\
\hline Umbanda & 4 & 7.8 \\
\hline Deist & 1 & 1.9 \\
\hline Atheist & 1 & 1.9 \\
\hline
\end{tabular}

Note: minimum wage was BRL 788 in the period.

Patients had lived with the diagnosis for $9.92 \pm 6.34$ years, with use of antiretroviral therapy for $8.47 \pm 5.72$ years. Mean prior hospitalizations was $1.29 \pm 1.91$. A total of 19 patients $(36.5 \%)$ presented a comorbidity, $18(34.6 \%)$ presented two or more, and 15 (28.9\%) presented no comorbidities/opportunistic infections. The main associated diseases were pneumonia $(15 ; 28.9 \%)$, syphilis $(13 ; 25.0 \%)$, tuberculosis $(12$; $23.1 \%$ ), and neurotoxoplasmosis $(6 ; 11.5 \%)$ (Table 2 ). 
Table 2 - Clinical data of patients of a reference HIV/Aids outpatient clinic, Recife, Pernambuco, Brazil, 2015

\begin{tabular}{lcc}
\hline Variables & Mean & Standard deviation \\
\hline Time since diagnosis (years) & 9.92 & 6.34 \\
Prior hospitalizations & 1.29 & 1.91 \\
Antiretroviral therapy time (years) & 8.47 & 5.72 \\
\hline Associated diseases & $\mathbf{n}$ & $\mathbf{\%}$ \\
\hline No diseases & 15 & 28.9 \\
Pneumonia & 15 & 28.9 \\
Syphilis & 13 & 25.0 \\
Tuberculosis & 12 & 23.1 \\
Neurotoxoplasmosis & 6 & 11.5 \\
Diabetes & 4 & 7.7 \\
Hypertension & 4 & 7.7 \\
Herpes zoster & 3 & 5.7 \\
Hepatite & 2 & 3.9 \\
Bronchitis & 1 & 1.9 \\
Cryptococcosis & 1 & 1.9 \\
Moniliasis & 1 & 1.9 \\
Leishmaniasis & 1 & 1.9 \\
Kaposi's Sarcoma & 1 & 1.9 \\
Non-Hodgkin lymphoma & 1 & 1.9 \\
One comorbidity & 19 & 36.5 \\
Two or more comorbidities & 18 & 34.6 \\
\hline
\end{tabular}

The sample showed high organizational religiosity $(4.23 \pm 1.66)$, non-organizational religiosity $(4.63 \pm 1.50)$, and intrinsic religiosity $(13.13 \pm 2.84)$. Positive RCOPE was used in high mean scores (3.66 \pm 0.88$)$, and negative RCOPE had low use (2.12 \pm 0.74$)$. In total, use of RCOPE was high $(3.77 \pm 0.74)$, having predominated the positive RCOPE (NegRCOPE/PosRCOPE ratio $=0.65 \pm 0.46$ ).

The positive factors that showed high use by patients were transformation of self and/or life $(4.11 \pm 1.09)$ and personal pursuit of spiritual growth $(4.11 \pm 1.06)$, positive attitude in relation to God ( $3.95 \pm 0.73)$, detachment by means of God, religion, and/ or spirituality $(3.90 \pm 1.29)$. The factor with the lowest use was actions in pursuit of spiritual help $(2.83 \pm 1.20)$, probably because it is less associated with diseases with the chronicity of the disease. Considering the negative factors, all had low use (Table 3 ).

Organizational religiosity had no significant association with any sociodemographic variable tested, nor with time since diagnosis. The non-organizational and intrinsic dimensions had weak to moderate association with age $(p=0.037 ; p=0.028)$.

With regard to coping, PosRCOPE showed weak to moderate association with age $(r=0.285 ; \mathrm{p}=0.041)$, and NegRCOPE showed moderate inverse in relation to years of education $(r=-$ $0.337 ; p=0.014)$. These results indicate that, in the sample, with age increases the use of positive factors of religious/spiritual coping and that the lower the educational level the higher the use of negative factors. Time since diagnosis had no significant association with religiosity, nor with coping, noting that the sample was selected with a time since diagnosis of at least

Table 3 - Results of the evaluation of religiosity and religious/spiritual coping of patients of a reference HIV/Aids outpatient clinic, Recife, Pernambuco, Brazil, 2015

\begin{tabular}{|c|c|c|c|c|}
\hline & Mean & Standard Deviation & Minimum & Maximum \\
\hline Organizational religiosity & 4,23 & 1,66 & 1,00 & 6,00 \\
\hline Non-organizational religiosity & 4,63 & 1,50 & 1,00 & 6,00 \\
\hline Intrinsic religiosity & 13,13 & 2,84 & 3,00 & 15,00 \\
\hline PosRCOPE & 3,66 & 0,88 & 1,00 & 4,74 \\
\hline NegRCOPE & 2,12 & 0,74 & 1,00 & 3,95 \\
\hline Total RCOPE & 3,77 & 0,56 & 1,81 & 4,76 \\
\hline NegRCOPE/PosRCOPE ratio & 0,65 & 0,46 & 0,26 & 2,73 \\
\hline \multicolumn{5}{|l|}{ PosRCOPE factors } \\
\hline Transformation of self and/or own life & 4,11 & 1,09 & 1,00 & 5,00 \\
\hline Actions in pursuit of spiritual aid & 2,83 & 1,20 & 1,00 & 5,00 \\
\hline Offer help to another one & 3,55 & 1,03 & 1,00 & 5,00 \\
\hline Positive attitude in relation to God & 3,95 & 0,73 & 1,00 & 4,73 \\
\hline Personal quest for spiritual growth & 4,11 & 1,06 & 1,00 & 5,00 \\
\hline Actions in pursuit of the institutional other & 3,53 & 1,08 & 1,00 & 5,00 \\
\hline Personal quest for spiritual knowledge & 3,25 & 1,21 & 1,00 & 5,00 \\
\hline Detachment by means of God, religion, and/or spirituality & 3,90 & 1,29 & 1,00 & 5,00 \\
\hline \multicolumn{5}{|l|}{ NegRCOPE factors } \\
\hline Negative re-evaluation of God & 1,98 & 1,03 & 1,00 & 4,75 \\
\hline Negative attitude in relation to God & 2,39 & 1,07 & 1,00 & 5,00 \\
\hline Negative reassessment of significance & 2,43 & 1,27 & 1,00 & 5,00 \\
\hline Dissatisfaction with the institutional other & 1,66 & 0,90 & 1,00 & 4,50 \\
\hline
\end{tabular}

Note: $R C O P E=$ religious/spiritual coping 
Table 4 - Correlations between religiosity and religious/spiritual coping and sociodemographic variables and time since diagnosis, Recife, Pernambuco, Brazil, 2015

\begin{tabular}{lccccccccc}
\hline \multicolumn{1}{c}{ Variables } & \multicolumn{2}{c}{ Age } & \multicolumn{2}{c}{ Education level } & \multicolumn{2}{c}{ Income } & \multicolumn{2}{c}{ Time of diagnosis } \\
& $\mathbf{r}$ & $\mathbf{p}$ & $\mathbf{r}$ & $\mathbf{p}$ & $\mathbf{r}$ & $\mathbf{p}$ & $\mathbf{r}$ & $\mathbf{p}$ & \\
\hline Organizational religiosity & 0.248 & 0.076 & 0.201 & 0.154 & 0.073 & 0.607 & 0.082 & 0.565 \\
Non-organizational religiosity & 0.29 & 0.037 & 0.272 & 0.051 & 0.116 & 0.411 & 0.216 & 0.124 \\
Intrinsic religiosity & 0.305 & 0.028 & 0.211 & 0.134 & 0.051 & 0.719 & 0.23 & 0.102 \\
PosRCOPE & 0.285 & 0.041 & 0.261 & 0.062 & 0.052 & 0.713 & 0.054 & 0.702 \\
NegRCOPE & -0.107 & 0.452 & -0.337 & 0.014 & -0.271 & 0.052 & -0.037 & 0.795 \\
Total RCOPE & 0.297 & 0.033 & 0.431 & 0.001 & 0.222 & 0.114 & 0.068 & 0.633 \\
NegRCOPE/PosRCOPE ratio & -0.199 & 0.157 & -0.33 & 0.017 & -0.145 & 0.304 & -0.117 & 0.409 \\
\hline
\end{tabular}

Note: $R C O P E=$ religious/spiritual coping; $r=$ Pearson correlation coefficient.

Table 5 - Correlations between religiosity and religious/spiritual coping in patients of a reference HIV/Aids outpatient clinic, Recife, Pernambuco, Brazil, 2015

\begin{tabular}{|c|c|c|c|c|c|c|}
\hline \multirow{2}{*}{ Variables } & \multicolumn{2}{|c|}{ OR } & \multicolumn{2}{|c|}{ NOR } & \multicolumn{2}{|c|}{ IR } \\
\hline & $r$ & p & $r$ & p & $r$ & p \\
\hline PosRCOPE & 0.485 & $<0.001$ & 0.644 & $<0.001$ & 0.766 & $<0.001$ \\
\hline NegRCOPE & -0.063 & 0.657 & -0.018 & 0.898 & -0.219 & 0.119 \\
\hline Total RCOPE & 0.342 & 0.013 & 0.522 & $<0.001$ & 0.753 & $<0.001$ \\
\hline NegRCOPE/PosRCOPE ratio & -0.339 & 0.014 & -0.491 & $<0.001$ & -0.733 & $<0.001$ \\
\hline
\end{tabular}

Note: OR: organizational religiosity; NOR: non-organizational religiosity; IR: intrinsic religiosity; $R C O P E=$ religious/spiritual coping; $r=$ Pearson correlation coefficient; $p=p$-value.

one year, based on the empirical assumption that the closer to diagnosis the more the patient may have increased spiritual needs and that, after one year, there is no significant difference considering the adaptation to the new reality (Table 4).

PosRCOPE had moderate and significant association with all dimensions of religiosity observed, mainly with intrinsic religiosity $(r=0.76 ; p<0.001)$. NegRCOPE had virtually no association with religiosity, with no significant correlation. Total RCOPE - which represents the mean of all factors used - had significant relation with the three dimensions of religiosity evaluated, noting the moderate to strong association with intrinsic religiosity $(r=0.75 ; p<0.001)$. These stronger associations with intrinsic religiosity indicate the reality that, in the sample, rather than the frequency of religious community or learned daily practice, individual values and beliefs are more important for coping with the disease and living with HIV/Aids (Table 5).

The ratio between negative and positive coping had moderate inverse association with the dimensions of religiosity, noting that the lower its value the higher the use of positive RCOPE strategies (Table 5).

\section{DISCUSSION}

Regarding the sociodemographic variables of the individuals interviewed, most were male, aged over 50 years, single or without companions, retirees, with income of up to 1.5 minimum wage. Most respondents considered themselves catholics, followed by evangelicals. These sociodemographic variables showed similarity with those of another study already reproduced in Brazil ${ }^{(8)}$. Taking into account the diagnosis of HIV, considered a chronic disease, greater investment in health is required, due to the need of continuous treatment, focusing not only on the disease but on the individual's quality of life ${ }^{(9)}$.

As to time since diagnosis, respondents had already lived with HIV for a mean of $9.92 \pm 6.34$ years, and used ART for a mean of $8.47 \pm 5.72$ years. In a similar study, the time since diagnosis of patients ranged from 1 to 28 years, with a mean of $6.25 \pm 4.91$, and $88 \%$ used $\mathrm{ART}^{(10)}$. Early awareness of one's serological condition is a positive factor for the prognosis of HIV/Aids, as it enables initiating ART, providing reduction of viral load, improvement of the individual's clinical conditions and, consequently, of quality of life ${ }^{(11-12)}$.

As to comorbidities related to Aids, pneumonia was the disease that affected most respondents, followed by syphilis, tuberculosis, and neurotoxoplasmosis. In another national study, 50\% of immunodeficient patients showed neurological infection ${ }^{(13)}$. Opportunistic pulmonary infections, such as tuberculosis and bacterial pneumonias, are more frequent in immunosuppressed patients ${ }^{(14)}$. In a retrospective study carried out with 225 patients in four Japanese hospitals from 1985 to 2012 on opportunistic diseases that affect PLWHA, 29.3\% presented pneumonia, $2.7 \%$ tuberculosis, and $4.9 \%$ neurotoxoplasmosis ${ }^{(14)}$.

With regard to religion, the three dimensions evaluated presented in high scores (organizational religiosity: $4.23 \pm 1.66$; non-organizational religiosity: $4.63 \pm 1.50$; and intrinsic religiosity: $13.13 \pm 2.84)$. The significant positive correlations between the three domains assessed and the positive religious/ spiritual coping show that, for the studied sample, the higher the religiosity the more it was used to cope with the disease. 
Religion has been associated with better condition to deal with the problems developed by feelings of helplessness and denial experienced by PLWHA. Individuals who reported having religion presented higher levels of satisfaction in life, leading to better adherence to $\mathrm{ART}^{(15)}$. Religiosity and spirituality have been shown as significant coping strategies among this specific population ${ }^{(15-17)}$.

PosRCOPE was used in high mean scores $(3.66 \pm 0.88)$, and NegRCOPE had low use $(2.12 \pm 0.74)$. In total, use of RCOPE was high $(3.77 \pm 0.74)$, having predominated the positive RCOPE (NegRCOPE/PosRCOPE ratio $=0.65 \pm 0.46$ ).

According to this study, respondents consider religiosity/ spirituality as something important in coping with HIV, showing high score for total religious/spiritual coping. Moreover, positive coping was more used than negative coping, which corroborates results obtained in another study ${ }^{(18)}$. Becoming aware of the importance of religiosity/spirituality can help the nursing professional create a greater bond, of trust, with the patient, in order to establish religious coping strategies.

Individuals with lower educational level were those who most used negative scores for religiosity/spirituality. Studies show that low socioeconomic power and low educational level are predominant factors in HIV-positive patients, and that they are also related to low adherence to treatment and to nonpursuit of better quality of life ${ }^{(19)}$. However, with respect to religiosity and educational level, other studies show otherwise: the lower the educational level the higher the pursuit of religiosity/spirituality ${ }^{(20)}$.

When RCOPE was associated with religiosity index, we observed strong association between RCOPE and intrinsic religiosity, which proves that the more the individual experiences religion completely the more positively this individual copes with the disease.

With a sample of 178 young or adolescent women and aiming to identify relations between the stigma of the disease and adherence to drug therapy, researchers concluded that religious/spiritual coping is a widely used strategy to cope with the stigma and increase adherence ${ }^{(21)}$. In a sample of PLWHA of both sexes, results of another study indicate that the spiritual well-being is a predictor of better coping with the stigma of the disease, measured in levels of associated depression ${ }^{(22)}$.

In relation to adherence, a specific study comparing adhering and non-adhering patients in one year showed that religiosity and relation with God, trust in God and in His power, prayers, and participation in religious groups were significantly greater factors in the group of adhering patients ${ }^{(23)}$.

RCOPE has a fundamental role in adapting to life with HIV/ Aids. A cohort of ten years with 177 PLWHA showed that, when dealing with situations that are potentially traumatic and of difficult adaptation - as approaching death, suffering from the stigma of the disease, poverty and limitations - most patients use spiritual coping, half experienced comfort, empowerment, growth, transformation, and gratitude, and one third found significance for the disease in their lives and underwent a process of resignification ${ }^{(17)}$.

Following this line of research, an international publication analyzed the relations between RCOPE, religiosity, depressive symptoms, adherence to medication, and social support and various dimensions of self-reported quality of life, in a sample of 292 $\mathrm{PLWHA}^{(24)}$. Our study had a quite similar sample in relation to age, sex, treatment time, and other factors. Most interviewees prayed daily, attended institutions or participated in religious groups, and identified themselves as moderately or very religious. Patients who prayed daily and attended services weekly had better quality of life in the dimension related to mental health, better social support, spiritual and existential well-being, vitality, and overall health ${ }^{(24)}$.

An international study with 177 people living with HIV assessed whether spiritual coping would be related to the disease's development and to health behaviors (adherence, safe sex, less substance abuse). After six months with monthly meetings, PosRCOPE (65\%) was predominant in relation to NegRCOPE (7\%), although $28 \%$ showed no significant use of RCOPE. Spiritual coping was associated with lower use/abuse of substances. PosRCOPE was predictor of increased levels of CD4 + and lower viral load, suggesting psychoneuroimmunological pathways that justify the phenomenon observed ${ }^{(16)}$.

Another research, even more comprehensive, investigated the relations between PosRCOPE and viral load, CD4 count, quality of life, symptoms of HIV, depression, and spiritual well-being. A total of 429 patients with HIV/Aids were evaluated for one year, and positive RCOPE was associated with better positive results, as well as negative RCOPE was associated with worse results ${ }^{(25)}$.

Researches, to date, have emphasized the behavioral aspects of patients who live with HIV/Aids, such as sexual function and social support ${ }^{(26)}$. The works now presented support the international concern in making clear the need to address the religious/ spiritual issue, not only in the sphere of research but also by extrapolating these findings to changes in practice with patients ${ }^{(27)}$.

\section{Study limitations}

This study had as limitation a certain degree of difficulty during data collection, since the proposed theme enters the patient's privacy concerning the diagnosis of HIV and can cause a certain embarrassment in participating in the study, requiring the creation of a researcher-patient bond. In addition, the Religious/Spiritual Coping Scale is extensive and was applied in the Specialized Care Service while patients waited for the appointment with the specialist, also because of the nonpreparation of a nursing care plan in this service, which confirms the necessity of developing researches on the Systematization of Nursing Care (SNC) in relation to PLWHA.

\section{Contributions to the fields of nursing, public policy, and public health}

Considering that and the nurse's role in providing care to PLWHA, it is important to create a patient-professional bond, as well as include the religious/spiritual practice in this context, since it can assist in accepting the diagnosis, in coping with the disease, in behavioral change, and in improving adherence to ART, leading to better quality of life and, consequently, to decreased morbidity and mortality and transmissibility of the disease.

\section{CONCLUSION}

HIV/Aids is a disease of chronicity, marked by the stigma imposed by society on PLWHA. Furthermore, all the changes the disease brings to an individual's life, the effects of medicines, 
and the restrictions have negative effect on well-being and tend to favor depression and nonadherence to medication.

With this study, it was observed that religiosity and spirituality play an important role in coping with HIV, since the participants experience the intrinsic religiosity, and the religious/ spiritual coping was used significantly and positively.

Considering the findings, in order to promote religious/ spiritual coping, health professionals should use knowledge on religiosity and spirituality in their professional practice, because these are mechanisms that can help patients in accepting the disease and in improving the quality of life.

Researches shows that social and family support strengthens the coping of PLWHA. Studies such as this one, as well as the literature reviewed in the discussion of these results, endorse how important it is that professionals recognize spiritual needs and intervene in this regard. Fostering religious activity and RCOPE mechanisms seen in the past as inappropriate interventions in clinical practice - becomes increasingly more pressing in a holistic approach.

\section{REFERENCES}

1. Geocze L, Mucci S, Marco MA, Nogueira-Martins LA, Citero VA. Qualidade de vida e adesão ao tratamento anti-retroviral de pacientes portadores de HIV. Rev Saúde Pública[Internet]. 2010[cited 2015 Dec 07];44(4):743-9. Available from: http://www.scielo.br/pdf/rsp/ v44n4/19.pdf

2. Cohen et al. Prevention of HIV-1 infection with early antiretroviral therapy. N Engl J Med[Internet]. 2011[cited 2015 Dec 07];365(6):493505. Available from: http://www.nejm.org/doi/full/10.1056/NEJMoa1105243

3. Pence BW, Shirey K, Whetten K, Agala B, Itemba D, Adams J, et al. Prevalence of psychological trauma and association with current health and functioning in a sample of HIV-infected and HIV-uninfected Tanzanian adults. PLoS One[Internet]. 2012[cited 2015 Dec 07];7(5):e36304. Available from: http://www.ncbi.nlm.nih.gov/pmc/articles/PMC3351441/pdf/pone.0036304.pdf

4. McIntosh RC, Rosselli M. Stress and coping in women living with HIV: a meta-analytic review. AIDS Behav[Internet]. 2012[cited 2015 Dec 07];16(8):2144-59. Available from: http://www.ncbi.nlm.nih.gov/pubmed/22434282

5. Ferreira D, Favoreto C, Guimarães M. A influência da religiosidade no conviver com o HIV. Interface[Internet]. 2012 [cited 2015 Dec 07];16(41):383-94. Available from: http://www.scielo.br/pdf/icse/v16n41/aop2012.pdf

6. Panzini R, Bandeira, D. Escala de Coping Religioso-Espiritual (escala CRE): elaboração e validação de construto. Psicol Estud[Internet]. 2005[cited 2015 Dec 07];10(3):507-16. Available from: http://www.scielo.br/pdf/pe/v10n3/v10n3a18

7. Moreira-Almeida, Peres MF, Aloe F, Lotufo Neto F, Koenig HG. Versão em português da Escala de Religiosidade da Duke: DUREL. Rev Psiquiatr Clín[Internet]. 2008[cited 2015 Dec 07];35(1):31-2. Available from: http://www.scielo.br/pdf/rpc/v35n1/v35n1a06.pdf

8. Montarroyos UR, Miranda-Filho DB, César CC, Souza WV, Lacerda HR, Albuquerque MF, et al. Factores related to changes in CD4+ T-cell count over time in patients living with HIV/AIDS: A multilevel analysis. PLoS One[Internet]; 2014[cited 2015 Dec 07];9(2):e84276. Available from: http://www.ncbi.nlm.nih.gov/pubmed/24505247

9. Medeiros B, Silva J, Saldanha AAW. Determinantes biopsicossociais que predizem qualidade de vida em pessoas quem vivem com HIV/aids. Estud Psicol[Internet]. 2013[cited 2015 Dec 07];18(4):543-50. Available from: http://www.scielo.br/pdf/epsic/ v18n4/a01v18n4.pdf

10. Medeiros B, Saldanha AAW. Religiosidade e qualidade de vida em pessoas com HIV. Estud Psicol[Internet]. 2012 [cited 2015 Dec 07];29(1):53-61. Available from: http://www.scielo.br/pdf/estpsi/v29n1/a06v29n1.pdf

11. Gaspar J, Reis RK, Pereira FMV, Neves LAS, Castrighini CC, Gir E. Qualidade de vida de mulheres vivendo com o HIV/AIDS de um município do interior paulista. Rev Esc Enferm USP[Internet]. 2011[cited 2015 Dec 07];45(1):230-6. Available from: http://www.scielo. $\mathrm{br} / \mathrm{pdf} /$ reeusp/v45n1/32.pdf

12. Vyankandondera J, Mitchell K, Asiimwe-Kateeira B, Boer K, Mutwa P, Balinda JP, et al. Antiretroviral therapy drug adherence in Rwanda: Perspectives from patients and healthcare workers using a mixed-methods approach. AIDS Care[Internet]. 2013 [cited 2015 Dec 07];25(12):1504-12. Available from: http://www.ncbi.nlm.nih.gov/pubmed/23517180

13. Araújo TM, Barros LM, Caetano JA. Neurotoxoplasmosis boarding in patients with HIV/Aids in intensive care unit. Rev Enferm UFPE[Internet]. 2012 [cited 2015 Dec 07];6(5):1046-52. Available from: http://www.revista.ufpe.br/revistaenfermagem/index.php/revista/ article/download/2406/3750

14. Katano $\mathrm{H}$, Hishima T, Mochizuki M, Kodama Y, Oyaizu N, Ota $\mathrm{Y}$ et al. The prevalence of opportunistic infection and malignancies in autopsied patients with human immunodeficiency virus infection in Japan. BMC Infect Dis[Internet]. 2014[cited 2015 Dec 07];14:229. Available from: http://www.ncbi.nlm.nih.gov/pmc/articles/PMC4016795/pdf/1471-2334-14-229.pdf

15. Hansen NB, Harisson B, Fambro S, Bodnar S, Heckman TG, Sikkema KJ. The structure of coping among older adults living with HIV/AIDS and depressive symptoms. J Health Psychol[Internet]. 2013[cited 2015 Dec 07];18(2):198-211. Available from: http://journals.sagepub. com/doi/pdf/10.1177/1359105312440299

16. Kremer H, Ironson G, Kaplan L, Stuetzele R, Baker N, Fletcher MA. Spiritual coping predicts CD4-cell preservation and undetectable viral load over four years. AIDS Care[Internet]. 2015[cited 2015 Dec 07];27(1):71-9. Available from: http://www.ncbi.nlm.nih.gov/ pubmed/25297848 
17. Kremer $\mathrm{H}$, Ironson $\mathrm{G}$. Longitudinal spiritual coping with trauma in people with hiv: implications for health care. AIDS Patient Care STDs[Internet]. 2014[cited 2015 Dec 07];28(3):144-54. Available from: http://www.ncbi.nlm.nih.gov/pmc/articles/PMC3948611/pdf/ apc.2013.0280.pdf

18. Lee M, Nezu AM, Nezu CM. Positive and negative religious coping, depressive symptoms and quality of life in people with HIV. J Behav Med[Internet]. 2014[cited 2015 Dec 07];37(5):921-30. Available from: http://www.ncbi.nlm.nih.gov/pubmed/24469329

19. Harris J, Pillinger M, Fromstein D, Gomez B, Garris I, Kanetsky PA, Tebas P, Gross R. Risk factores for medication non-adherence in an infected population in the Dominican republic. AIDS Behav[Internet]. 2011[cited 2015 Dec 07];15(7):1410-5. Available from: http:// www.ncbi.nlm.nih.gov/pmc/articles/PMC3022963/.

20. Silva SK, Passos SMK, Souza LDM. Associação entre religiosidade e saúde mental em pacientes com HIV. Psicol Teor Prát[Internet]. 2015[cited 2015 Dec 07];17(2):36-51. Available from: http://editorarevistas.mackenzie.br/index.php/ptp/article/view/6553/5442

21. Martinez J, Harper G, Carleton RA, Hosek S, Bojan K,Glun G, et al. The impact of stigma on medication adherence among hiv-positive adolescent and young adult females and the moderating effects of coping and satisfaction with health care. AIDS Patient Care STDs[Internet]. 2012[cited 2015 Dec 07];26(2):108-15. Available from: http://www.ncbi.nlm.nih.gov/pmc/articles/PMC3266519/pdf/apc.2011.0178.pdf

22. Chaudoir SR, Norton WE, Earnshwn VA, Moneyham L, Mugavero MJ, Hiers KM. Coping with hiv stigma: do proactive coping and spiritual peace buffer the effect of stigma on depression? AIDS Behav[Internet]. 2012[cited 2015 Dec 07];16:2382-91. Available from: http://link.springer.com/article/10.1007\%2Fs10461-011-0039-3

23. Pecoraro A, Pacciolla A, O'Cleirigh C, Mimiaga M, Kwiatek P, Blokhina E, Verbitskaya E, Krupitsky E, Woody GE. Proactive coping and spirituality among patients who left or remained in antiretroviral treatment in St Petersburg, Russian Federation. AIDS Care[Internet]. 2015[cited 2015 Dec 07];13:1-6. Available from: http://www.ncbi.nlm.nih.gov/pubmed/26461806

24. Dalmida SG, Koenig HG, Holstad MM, Thomas TL. Religious and psychosocial covariates of health-related quality of life in people living with HIV/AIDS. HIV/AIDS Res Treat[Internet]. 2015[cited 2015 Dec 07];1(1):1-15. Available from: http://dx.doi. org/10.17140/HARTOJ-1-101

25. Trevino KM, Pargament KI, Cotton S, Leonard AC, Hahn J, Caprini-Faigin CA, Tsevat J. Religious coping and physiological, psychological, social, and spiritual outcomes in patients with HIV/AIDS: cross-sectional and longitudinal findings. AIDS Behav[Internet]. 2010[cited 2015 Dec 07];14(2):379-89. Available from: http://www.ncbi.nlm.nih.gov/pubmed/18064557

26. Lima TC, Freita MIP. Comportamentos em saúde de uma população portadora do HIV/Aids. Rev Bras Enferm[Internet]. 2012[cited 2015 Dec 07];65(1):110-5. Available from: http:/www.scielo.br/pdf/reben/v65n1/16.pdf

27. Szaflarski M. Spirituality and Religion among HIV-Infected Individuals. Curr HIV/AIDS Rep[Internet]. 2013 [cited 2015 Dec 07];10:324-32. Available from: http://link.springer.com/article/10.1007\%2Fs11904-013-0175-7 